UDC: $347.627 .2(4)$

\title{
COMPARATIVE ANALYSIS OF THE GROUNDS LEADING TO THE DISSOLUTION OF MARRIAGE WITHIN DIFFERENT EUROPEAN LAWS
}

\author{
Mădălina Dinu \\ $\mathrm{PhD}$ Associate Professor, Faculty of Law, \\ “Titu Maiorescu” University, Bucharest, Romania \\ E-mail:madalinaconstantin10@yahoo.com)
}

\begin{abstract}
Divorce is one of the first legal institutions that people have been confronted with since ancient times, given that the family has always been at the foundation of society. However, not all spouses respect the obligations they have taken upon themselves once with the conclusion of marriage, so that, when the obligations can no longer be fulfilled by the parties, they must resort to a legal remedy that may lead to either the delay in the fulfillment of the obligations, of to the termination of legal relations on grounds not attributable or attributable to the guilty party, or to both parties, where applicable.

Given that, depending on the specifics of the society to which they belong, the history of each state, the reasons leading to the dissolution of the marriage are different, the reasons found in the laws of European states differ. In this regard, in this study we aim to analyze the existing reasons in certain European states that may constitute grounds for divorce. Thus, the reasons leading to the dissolution of the marriage in Romania, France, and Italy shall be analyzed. We will note that the reasons are different, as well as the procedure that applies, being states in which the divorce procedure can be an administrative, notarial or judicial depending on the consent of the spouses at the dissolution of the marriage and/or whether there are minor children resulting from the aforementioned marriage.
\end{abstract}

Keywords: dissolution of marriage, guilt, de facto separation, divorce for medical reasons, non-patrimonial effects, legal separation

\section{General aspects}

The prerequisite for the existence of a marriage dissolution request, (regardless of whether the administrative or judicial procedure is followed), is the existence of a marriage.

Divorce constitutes that ,form of dissolution of marriage which consists in its dissolution, with effects for the future, by agreement of the parties or by court" 1 . $\mathrm{Ab}$ initio, we mention the fact that the dissolution of the marriage should not be confused with its termination. Thus while the termination of the marriage is seen as an ,indication of the natural and objective cases by which it ended (the death of one

1 F. A. Baias, Unele dispoziţii privind divorţul in noul Cod civil, in the Annals of the University of Bucharest - Law Series, no. 2011-III, July - September, p. 301 
of the spouses or the judicial declaration of death), while the dissolution of marriage represents the dissolution of marriage by divorce"2.

Divorce, although it is a non-patrimonial application, can have patrimonial effects in some states, such as, for example, in Romania, when the dissolution of the marriage is requested on grounds attributable to the defendant spouse, and the claimant requests payment of a compensatory benefit or compensation from them.

\section{Common elements of grounds for divorce that may lead to the dissolution of marriage in Romania and France and the applicable procedure}

In Romania, spouses can divorce administratively (before the Civil Officer) when the divorce is by mutual agreement and they do not have minor children resulting from said marriage or adopted, by notary (before the notary public) even if they have minor children, but the spouses agree on all the ancillary aspects of the divorce (exercising the parental authority of the minors, establishing their domicile, the name that the spouses will bear after the dissolution of the marriage, the program on personal relationships with the minor established with the parent with whom the minor will not reside) or, in the event that the spouses cannot come to a mutual agreement, they may file a claim to the competent court. In other words, in Romania, the dissolution of the marriage can take place:a) before the Civil Officer; 2) before the notary public; c) before the court.

The reasons that determine the dissolution of the marriage through divorce, as well as its effects are regulated by the Civil Code in the content of Article 373-404.

The reasons for divorce are provided by Article 373 of the Romanian Civil Code, and the divorce may take place ${ }^{3}$ :

- by consent of the spouses, at the request of both spouses or of one of the spouses accepted by the other spouse;

- when, for good cause, the relationship between the spouses is severely damaged and the continuation of the marriage is no longer possible, in which case the divorce may be pronounced as by common fault or the sole fault of one of the spouses;

- at the request of one of the spouses, following a de facto separation that has lasted for at least two years; in this case, the spouses must have been separated for at least 2 years, in which case the divorce may be granted at the request of either of them, if the applicant takes on the responsibility for the failure of the marriage, in which case the decision in favor of the dissolution the marriage will be blamed on the applicant, in accordance with the provisions of Article 935 of the Romanian Civil Procedure Code.

\footnotetext{
2 I. Albu, Dreptul familiei, Didactică şi Pedagogică Publishing House, Bucharest, 1975, pag. 179, qtd. in I. Leş, Proceduri civile speciale, All Beck Publishing House, 2000, pag. 105

${ }^{3}$ G.Boroi, M.Stancu, Drept procesual civil, $4^{\text {th }}$ Ed., Hamangiu Publishing House, Bucharest, 2017, p. 858
} 
- at the request of the spouse whose state of health makes the continuation of the marriage impossible, situation in which the divorce can be pronounced by invoking and proving a reason relative to the state of health of one of the spouses that would make it impossible to continue the marriage, according to the provisions of Article 933 of the Romanian Civil Procedure Code.

These ways of dissolving the marriage regulated in the Romanian legislation are similar to those provided in French law, under the name of starting divorce actions. Thus, the French legal system regulates the following reasons leading to the dissolution of marriage, bearing the following names: (a) divorce on the grounds of fault, (b) divorce due to irretrievable breakdown of the marriage, (c) divorce by acceptance and (d) divorce by mutual consent ${ }^{4}$.

In the Romanian legal system, in addition to the main purpose of the application, the court will rule, upon request, on the ancillary aspects specific to the divorce procedure: the exercise of parental authority, the maintenance pension, the child's home, the right of the parent who was not entrusted with the minor to have personal relations with him, the names of the spouses after the divorce, the family home, the maintenance obligation or the compensatory benefit between the ex-spouses, the termination of the matrimonial regime and, as the case may be, the liquidation of property and assets.

Establishing the minor child's domicile, after the dissolution of the marriage, follows the criterion of the child's best interest. We mention the fact that this establishment of the child's domicile is not directly determined by the establishment of the exercise of parental authority. Thus, the home of the child will be established by the mutual agreement of the parents, and if said decision is contrary to the best interests of the child, the court will rule for: establishing the residence of the minor with the parent with whom they live permanently, or with one of the parents in the situation in which the parents lived together before the divorce or, exceptionally, if it is in the best interests of the child, with the grandparents, other relatives or persons, with their consent, or to a protection institution, in accordance with the provisions of Article 400 (3) of the Romanian Civil Code.

At the same time, the Romanian Civil Code provides for two cases that represent actions that can be formulated only as ancillary once with the filing for divorce ${ }^{5}$. Thus, in accordance with Article 388 of the Romanian Civil Code, the spouse innocent of the dissolution of the marriage may obtain, from the guilty spouse, exclusively in the dissolution of the marriage, compensation, insofar as they will prove the damage suffered was a result of the dissolution of the marriage. The claim for compensation will be resolved by the divorce decision. We encounter the same situation in the

4 G. Serra, L. W. Pellitteri, Droit du divorce, in Dalloz no. 9/7282 of March 1, 2007, p. 608, qtd in C.C.Dinu, Proceduri speciale în noul cod de procedură civilă, Universul Juridic Publishing House, 2013, p. 50

${ }^{5}$ C.C.Dinu, Dreptul procesual civil și activitatea notarială, Notarom Publishing House, Bucharest, p.202 
case of the compensatory benefit regulated by Article 390 of the Romanian Civil Code, obligation to be paid by the guilty spouse exclusively in the dissolution of the marriage in favor of the innocent spouse, if the duration of the marriage was of at least 20 years. With regard to the formulation of such a claim, Article 391 (1) of the Romanian Civil Code provides that the granting of the compensatory payment shall be decided by the court only "once with the dissolution of the marriage".

It can be seen that both the indemnities for the dissolution of the marriage and the compensatory benefit imply the exclusive fault of one of the spouses, which makes these legal provisions inapplicable in the case of notarial divorce, even less in the case of divorce before the Civil Officer. If one of the spouses intends to obtain compensation or compensatory benefits together with the divorce, they will have to initiate the legal procedure of divorce in order to retain the exclusive fault of the other spouse.

At the same time, if the spouses have decided to divorce by notary; after this divorce they will not be able to request separate compensations or compensatory benefit because the notarial divorce does not imply the notion of guilt, these requests can be attached only as ancillary in a divorce application filed to the court.

Regarding the notarial procedure of divorce, it can interfere with the judicial procedure of divorce, however it is not conditioned by it. The fact that a divorce application is pending before a court does not create an impediment to the initiation and conduct of the notarial divorce proceedings. This solution is also enshrined in Article 277 of the Regulation on the conduct of Romanian notarial activity, which does not provide for any case of rejection of the divorce application if there is, at the same time, a divorce application pending before a court. Only in the case in which the divorce is pronounced in court, the notary public will issue a decision rejecting the divorce application due to the application lacking an object, as the marriage between the spouses has been dissolved by another competent authority (Article $277 \mathrm{k}$ ) of the Regulation on Notary Activity ${ }^{6}$ ).

Regarding the personal appearance of the spouses in the Romanian legal system, they have the obligation to appear in person at the deadline set for the dissolution of the marriage in the case of the notarial procedure and the Civil Officer. In the event that the divorce is to be decided in court, the plaintiff may file for divorce by authorized representative, but has the obligation to appear in person before the court under the sanction of rejecting the application for dissolution of marriage as unsubstantiated, according to the provisions Article 922 of the Romanian Civil Code. By way of exception, if one of the spouses is serving a custodial sentence, is prevented through serious illness, is placed under a court injunction, has his or her domicile abroad or is in another situation such as prevents him or her from appearing personally; in such situations, the person concerned may be represented by a lawyer, authorized representative or, where appropriate, guardian or registered representative.

6 C.C.Dinu, op.cit., p.204 
The solution regarding the personal appearance of the spouses before the court is nuanced in the French legislation, the aforementioned being mandatory only if the spouse seeks urgent measures, according to the provisions of Article 1106 of the French Civil Procedure Code.

In what concerns the attempt at conciliation of the parties by the court of trial which must rule in the matter of the divorce, the regulations in the Romanian and French legislations differ. Thus, while in the Romanian system, the judge has the obligation to try to reconcile the parties at each appearance before the court, according to the provisions Article 921(2) of the Romanian Civil Procedure Code, in French law there is a mandatory prior procedure before notifying the court, governed by the provisions of Article 1108 - 1113 of the French Civil Procedure Code, and the completion of this procedure has an effect on the admissibility of the divorce application, in the sense that if, prior to the referral to the court with the divorce application, this preliminary procedure is not followed, the divorce application will be subject to the penalty of nullity.

\section{The grounds for divorce that may lead to the dissolution of marriage in Italy as opposed to Romania and France}

Given that the divorce application is of a personal nature, in the Romanian legislation, it can be introduced by the creditors of one of the spouses, by way of a possible oblique action, and the prosecutor does not have the active procedural quality regarding the application for the dissolution of the marriage. However, the prosecutor can draw conclusions in any divorce proceedings, during any stage, if they deem it necessary to defend the rule of law or the rights and interests of the parties under the conditions of Article 94 (2) of the Romanian Civil Procedure Code, such as in the case of protecting the interests of minors resulting from marriage.

Unlike the Romanian and French legal systems, in which the involvement of the prosecutor is not mandatory, in the Italian legal system the involvement of the prosecutor is mandatory.

Also, another fundamental difference from the two legal systems is the fact that divorce cannot be pronounced exclusively by the mutual agreement of the spouses, in addition to their consent there being necessary to have well-founded grounds to support the divorce application.

Well-founded grounds, within the meaning of Italian divorce law ${ }^{7}$, are:

- the other spouse is sentenced by final judgment for a particularly serious crime, (with the exception of political offences); particularly serious crimes being understood as: incest, sexual offences, murder or attempted murder of their

${ }^{7}$ M.Dinu, C.M.Ioana, Procedura divorțului în alte state membre U.E. Italia. Cipru. Finlanda, paper presented at the Conference on Law of European Studies and International Relations between 14-15 May 2020 at Titu Maiorescu University of Bucharest 
child or of their spouse, grievous bodily harm, failure to fulfill family support obligations and other such offences.

- the couple have been legally separated, either by mutual consent or on the application of one of the parties, for an uninterrupted period of 3 years;

- the marriage has not been consummated,

- one of the spouses has officially changed sex;

- the other spouse, being a foreign national, has obtained the annulment or dissolution of the marriage abroad or has entered into a new marriage abroad.

The legal consequences of divorce in Italy influence the personal relations between the spouses, the property of the spouses, the parental authority over the minor child (if there are any) and the obligation to pay maintenance of the other spouse (if applicable), some of which can also found in the legislation of France and Romania.

Unlike Romania, where the spouses are the ones who establish the name they are to bear after marriage, each being able to either take the other's name or hyphenate their names, or keep the individual surnames they had before marriage, in Italy the wife takes the husband's surname. However, as in the divorce procedure in Romania, in Italy, after the divorce is pronounced, the wife will return to the name she originally had (however, according to Romanian law, if the other spouse so agrees, the spouse can keep the name used during the marriage). In Italy, by exception, the husband keeps his surname, however, on application, the court may allow the woman to retain her husband's surname where this is shown to be in her interest or in the children's interest, facet which also exists in Romanian law.

\section{Legal separation, an alternative to divorce in Italian law?}

Romanian law does not regulate the institution of "legal separation", but for the citizens of the Italian state this is an alternative to the divorce procedure that spouses resort to when they no longer cohabitate. This is due to the fact that unlike Romanian and French law, which allows spouses to divorce by mutual agreement, Italian law is much more restrictive in the grounds for divorce, so that there is a possibility that the spouses may wish to divorce but do not fall within any of the grounds set out in law. In this case, the spouses can appeal to the institution of legal separation, which means that after a separation of 3 years they can divorce. However, the mere de facto separation of the spouses is not a sufficient premise for granting the divorce in 3 years, but the separation must be ascertained by a court decision or by an express mutual agreement of the spouses (tacit agreement is not sufficient).

With regard to judicial separation, for the court to rule on such a decision, the consent of both spouses is not required, but only one of them must make such a request, however, it is necessary for the court to establish that the spouses can no longer cohabitate, in which case the court will order legal separation. In this procedure, the court may also find the exclusive responsibility of one of the spouses, 
in which case he will pronounce the legal separation through his sole fault, in which case, the guilty spouse will not be able to inherit the other spouse if the latter dies within 3 years. Such a solution does not exist in Romanian law, the marriage ending in the event of the death of one of the spouses; even if at the time of death the divorce proceedings were pending before the court, in the absence of a final decision, the other spouse will have the quality of surviving spouse and will inherit the deceased spouse. The Romanian legislation also allows for derogation from this rule, however, in a single situation. Thus, the divorce proceedings will continue, if the plaintiff spouse dies during the trial, and the following conditions, provided in the table of contents Article 926 (2) of the Romanian Civil Procedure Code are met, respectively, the divorce application is based on the guilt of the defendant spouse, the plaintiff dies during the trial, leaving heirs who request the continuation of the divorce proceedings. In case of continuation of the divorce, the court will admit the divorce action only if it finds the exclusive responsibility of the defendant. Per a contrario, if this exclusive fault is not found by the court, there being a common fault, or the exclusive fault of the plaintiff, the court will issue a final decision on the closure of the case, according to the provisions Article 926 (2) of the Romanian Civil Procedure Code.

Legal separation can occur, according to the Italian regulation, also in the case of an express agreement between the spouses, case in which the duty of the court of a solely formal nature, the only aspect which is to be verified by the court in this case being that by this mutual agreement of the spouses the good interests of the child bear no damage, the court having the possibility to call on the parties to remedy the situation so that the interests of the minor are not harmed in order to pronounce the legal separation. If the parties do not comply, the court can reject the application.

\section{Conclusions}

The grounds leading to the dissolution of the marriage in the three states subject to the analysis possess both similar elements and dissimilar elements. Nevertheless, the spouses must be offered legislative solutions for terminating the marriage when cohabitation is no longer a valid option for the two. As established in the old doctrine on the subject matter, "since the faith owed to their spouse no longer exists, but has become a dishonest situation, behind which illicit relationships are hidden, or that the soul bond between the spouses can no longer exist, and has been replaced by contempt. Aversion and hostile relationships, these are not in the interest of children, family or society to impose the maintenance of a legal situation that no longer corresponds to reality ${ }^{8 .}$.

\footnotetext{
${ }^{8}$ M.B. Cantacuzino, Elementele dreptului românesc, Cartea Românească Publishing House, Bucharest, 1921, p. 683
} 


\section{REFERENCES}

\section{Books}

1. .F. A. Baias, Unele dispoziții privind divorţul in noul Cod civil, in the Annals of the University of Bucharest - Law Series, no. 2011-III, July - September

2. I. Albu, Dreptul familiei, Didactică şi Pedagogică Publishing House, Bucharest, 1975, pag. 179, qtd. in I. Leş, Proceduri civile speciale, All Beck Publishing House, 2000

3. G.Boroi, M.Stancu, Drept procesual civil, $4^{\text {th }}$ Ed., Hamangiu Publishing House, Bucharest, 2017

4. G. Serra, L. W. Pellitteri, Droit du divorce, in Dalloz no. 9/7282 of March 1, 2007, p. 608, qtd in C.C.Dinu, Proceduri speciale în noul cod de procedură civilă, Universul Juridic Publishing House, 2013

5. C.C.Dinu, Dreptul procesual civil și activitatea notarială, Notarom Publishing House, Bucharest

6. M.B. Cantacuzino, Elementele dreptului românesc, Cartea Românească Publishing House, Bucharest, 1921, p. 683

\section{Journals}

- M.Dinu, C.M.Ioana, Procedura divorțului în alte state membre U.E. Italia. Cipru. Finlanda, paper presented at the Conference on Law of European Studies and International Relations between 14-15 May 2020 at Titu Maiorescu University of Bucharest 